\title{
INTERFERENSI BAHASA SUNDA TERHADAP BAHASA INDONESIA DALAM KARANGAN DESKRIPSI SISWA KELAS VII
}

\author{
Anne Andriani \\ Fakultas Pascasarjana, Universitas Indraprasta PGRI, Jakarta \\ ane_anya@yahoo.com
}

\begin{abstract}
ABSTRAK
Tujuan penelitian adalah untuk mendeskripsikan terjadinya interferensi morfologi dan sintaksis bahasa Sunda terhadap bahasa Indonesian dalam karangan deskripsi siswa, tataran ketatabahasaan yang paling banyak dipengaruhi, dan faktor-faktor penyebab terjadinya interferensi morfologi dan sintaksis. Penelitian ini menggunakan metode deskriptif dengan objek penelitian berupa karangan deskripsi siswa yang memiliki bahasa kesatu bahasa Sunda. Dari hasil analisis data, peneliti menyimpulkan bahwa terjadi interferensi bahasa Sunda terhadap bahasa Indonesia dalam karangan deskripsi siswa. Aspek-aspek kebahasaan yang paling banyak dipengaruhi adalah aspek morfologi. Secara keseluruhan karangan deskripsi siswa kelas VII SMPN 1 Nanggung, Kabupaten Bogor kurang mengandung interferensi. Faktor-faktor penyebab terjadinya interferensi karena pemakaian bahasa Sunda yang dominan dan kemiripan serta ketiadaan padanan dalam bahasa Sunda dengan bahasa Indonesia atau sebaliknya.
\end{abstract}

Kata Kunci: interferensi morfologi,interferensi sintaksis, bahasa Sunda

\begin{abstract}
The aim of the research is to describe the occurance of morphology interference and the syntax of sundanesse language toward Indonesian in student's writing, the gramatical aspect that mostly influenced, and the factors that causes. This research uses descriptive method with the object of the research in student's writing which has the first language Sundanesse. From the results of data analysis, researcher concludes that the interference occurs in Sundanesse toward Indonesian in their writings. The aspect of language that mostly influenced is the morphology. As the whole descriptive writings of the students of class VII SMPN 1 Nanggung have less of interference. The factors that causes the interference is the use of Sundanesse dominately and the similarities and no subtitude in Sundanesse language to Indonesian.
\end{abstract}

Keyword : morfology interference, syntax interference, Sundaness language.

\section{PENDAHULUAN}

Latar Belakang

Manusia adalah makhluk sosial yang tidak dapat hidup sendiri dalam masyarakat. Pada hakikatnya manusia sebagai individu tidak akan dapat memenuhi kebutuhannya sendiri. Hal tersebut baru dapat dipenuhi apabila manusia berada dalam satu kelompok masyarakat dan mengadakan interaksi satu sama lain. Interaksi membutuhkan media untuk berkomunikasi. Bahasa adalah media yang tepat sebagai alat komunikasi. 
Bahasa sebagai alat komunikasi sejalan dengan pendapat Lapasau dkk (2016:2) bahwa bahasa merupakan salah satu alat komunikasi, artinya alat untuk berhubungan dengan sesama anggota masyarakat, berhubungan dengan Tuhannya, dan lingkungannya.

Umumnya, masyarakat Indonesia memperoleh dua bahasa bahkan mungkin di era teknologi informasi ini generasi muda banyak yang mengenal lebih dari dua bahasa. Sejak kecil, semua anak diperkenalkan pada bahasa daerah yang biasa dinamakan bahasa ibu. Terutama anak-anak yang tinggal di daerah. Oleh karena itu, bahasa daerah disebut juga bahasa kesatu (B1) yaitu bahasa yang pertama kali dipelajari sebelum bahasa-bahasa yang lain. Ketika anak-anak ini berinteraksi dengan lingkungannya yaitu lingkungan sekitar rumah, lingkungan sekolah, dan media sosial, barulah timbul kontak antara bahasa kesatu (B1) dengan bahasa kedua (B2).

Bilingualisme atau kedwibahasaan sangat umum dikenal sebagai kemampuan menggunakan dua bahasa. Nababan (1991: 27) mengemukakan bahwa bilingualisme adalah kebiasaan menggunakan dua bahasa dalam berinteraksi dengan orang lain, sedangkan Kridalaksana (2008: 25) menyatakan bahwa yang dimaksud kedwibahasaan ialah penggunaan bahasa kebangsaan dan bahasa daerah secara berganti-ganti.

Karena fenomena dwibahasawan inilah sering terjadi bahasa kedua dipengaruhi oleh bahasa kesatu. Kenyataan seperti ini tidak hanya tampak pada anak dalam tahap awal pemerolehan bahasa, tetapi pada anak yang sudah melewati tahapan awal pemerolehan bahasa misalnya usia 13 tahun atau anak di kelas VII SMP.

Inilah yang dinamakan interferensi menurut Weinrich (dalam Chaer, 2010:120) yaitu perubahan sistem suatu bahasa sehubungan dengan adanya persentuhan bahasa tersebut dengan unsur-unsur bahasa lain yang dilakukan oleh penutur yang bilingual. Atau, interferensi adalah masuknya unsur serapan ke dalam bahasa lain yang bersifat melanggar kaidah gramatika bahasa yang menyerap. Sederhananya, interferensi adalah "kekeliruan" yang terjadi sebagai akibat terbawanya kebiasaan-kebiasaan ujaran bahasa ibu (B1) atau dialek ke dalam bahasa atau dialek kedua (B2). Interferensi bisa dalam bidang fonologi, morfologi, maupun sintaksis.

Weinrich dalam Fauziati (2016) mengungkapkan terjadinya interferensi dalam suatu bahasa, antara lain, disebabkan oleh faktor sebagai berikut: para peserta tutur; (2) tipisnya kesetiaan pemakai bahasa penerima; (3) tidak cukupnya kosakata bahasa penerima dalam menghadapi kemajuan dan pembaruan; (4) menghilangnya kata-kata yang jarang digunakan; (5) kebutuhan akan sinonim; (6) prestise bahasa sumber dan gaya bahasa. Di samping itu, ditambahkan oleh Hartmann dan Stork (1972: 155) bahwa interferensi terjadi pula karena terbawanya kebiasaan dari bahasa pertama atau bahasa ibu.

Suwito dalam Aslinda dan Syafyahya (2014: 67) menjelaskan bahwa interferensi dapat terjadi dalam semua komponen kebahasaan, yaitu bidang tata bunyi, tata kalimat, tata kata, dan tata makna. Agar tidak terlalu luas, peneliti membatasi interferensi pada morfologi dan sintaksis.

\section{Rumusan Masalah}

Rumusan penelitian ini adalah sebagai berikut.

1. Aspek-aspek kebahasaan apa saja yang paling banyak dipengaruhi morfologi bahasa Sunda.

2. Faktor-faktor apa saja penyebab terjadinya interferensi pemakaian bahasa Sunda yang dominan dan kemiripan serta ketiadaan padanan dalam bahasa Sunda dengan bahasa Indonesia atau sebaliknya. 


\section{Tujuan Penelitian}

Penelitian ini bertujuan untuk mendeskripsikan terjadinya interferensi morfologi dan sintaksis bahasa Sunda terhadap bahasa Indonesia dalam karangan deskripsi siswa kelas VII SMPN 1 Nanggung, Kabupaten Bogor.

\section{Kerangka Teori}

Bahasa Sunda adalah bahasa ibu atau bahasa kesatu (B1) yang diperoleh anak-anak kelas VII, SMPN 1 Nanggung, Kabupaten Bogor, sedangkan bahasa Indonesia adalah bahasa kedua (B2) yang diperoleh dari media elektronik, internet, dan baru mereka pelajari di usia sekolah dan digunakan sebagai bahasa resmi di sekolah.

Secara tidak langsung, siswa-siswa ini adalah dwibahasawan. Seperti menurut Nababan (1991: 27) bahwa bilingualisme adalah kebiasaan menggunakan dua bahasa dalam berinteraksi dengan orang lain, sedangkan Kridalaksana (2008: 25) menyatakan bahwa yang dimaksud kedwibahasaan ialah penggunaan bahasa kebangsaan dan bahasa daerah secara berganti-ganti. Peneliti sendiri membatasi pengertian kedwibahasaan sebagai penggunaan dua bahasa secara bergantian oleh seorang pembicara dalam situasi-situasi tertentu. Khususnya disini penggunaan bahasa Sunda dan Bahasa Indonesia.

Berdasarkan tahapan usia pemerolehan bahasa, Rusyana (1984: 35) membagi dwibahasawan ke dalam dua jenis, yaitu:

1) dwibahasawan anak-anak, yaitu mereka yang mempelajari B2 sebelum berumur 14 tahun, dan

2) dwibahasawan dewasa, yaitu mereka yang mempelajari B2 setelah berumur 14 tahun.

Siswa-siswa kelas VII umumnya berusia 12-14 tahun sehingga mereka termasuk ke dalam dwibahasawan anak-anak. Hal ini membuat mereka rentan melakukan interferensi bahasa. Interferensi akan terjadi manakala seseorang menjadi dwibahasawan. Pengacauan terjadi pada tataran-tataran kebahasaan yang diakibatkan oleh penggunaan dua bahasa tersebut.

\section{METODE PENELIIAN}

Jenis penelitian yang dilakukan adalah penelitian kualitatif deskriptif yaitu penelitian kualiltatif yang bersifat deksriptif yang dilakukan dengan menggambarkan dan menjelaskan data-data. Sebagaimana yang dikatakan Moleong (2009: 3) bahwa penelitian kualitatif yaitu prosedur penelitian yang menghasilkan data deskriptif berupa kata-kata tertulis atau lisan dari orang-orang dan perilaku yang diamati. Metode yang digunakan dalam penelitian ini adalah metode deskriptif. Metode deskriptif menurut Moleong (2009:11) adalah data yang dikumpulkan berupa kata-kata, gambar, dan bukan angka-angka. Dalam hal ini, metode tersebut akan dipergunakan untuk mendeskripsikan interferensi morfologi dan sintaksis pada karangan deskripsi siswa.

Penelitian deskriptif terdiri atas beberapa tipe atau jenis. Sudjana (1989:68) mengungkapkan bahwa penelitian deskriptif yang sering digunakan adalah (1) studi kasus, (2) studi pengembangan, (3) studi follow up, (4) analisis dokumenter, (5) analisis kecenderungan, (6) survey dan (7) studi korelasi. Dari jenis-jenis penelitian deskriptif 
tersebut, studi kasus merupakan jenis yang dipilih atau digunakan dalam penelitian ini. Kasusnya dalam hal ini adalah interferensi morfologi dan sintaksis bahasa Sunda terhadap bahasa Indonesia dalam karangan deskripsi siswa kelas VII, SMPN 1 Nanggung, Kabupaten Bogor tahun pelajaran 2018/2019.

Dalam penelitian ini yang menjadi sampel adalah karangan deskripsi siswa kelas VII SMPN 1 Nanggung, Kabupaten Bogor. Karangan yang diambil hanya pada siswa kelas VII saja yang berjumlah 9 kelas dengan jumlah rombongan belajar 36 siswa atau sejumlah 324 siswa. Sesuai dengan pendapat Arikunto (2010) jika jumlah populasi lebih dari 100, maka dapat diambil antara 10--15\%, 20--25\% atau lebih, tergantung setidak-tidaknya dari 1) kemampuan peneliti dilihat dari waktu, tenaga, dan dana, 2) sempit luasnya wilayah pengamatan dari setiap subjek, 3) besar kecilnya risiko yang ditanggung oleh peneliti.

Sesuai dengan poin yang pertama bahwa peneliti adalah seorang guru Bahasa Indonesia di sebuah SMA swasta dan mendapatkan tugas tambahan sebagai kepala perpustakaan yang sejatinya tidak boleh meninggalkan kewajiban dan tugasnya dalam mendidik dan mengajar, peneliti memutuskan untuk mengambil sampel sebesar 25\% atau 81 karangan siswa.

Hal ini juga sejalan dengan pendapat S. Nasution (dalam Sugiyono, 2009: 55) bahwa penentuan unit sampel (responden) dianggap telah memadai apabila sampai kepada taraf "redundancy" (datanya telah jenuh, ditambah sampel lagi tidak memberikan informasi yang baru), artinya bahwa dengan menggunakan responden selanjutnya boleh dikatakan tidak lagi diperoleh tambahan informasi baru yang berarti. Oleh karena itu, peneliti merasa cukup dengan jumlah sampel yang diambil agar tidak mengulang-ulang permasalahan yang sama dan menghindari kejenuhan dalam menganalisis data.

Teknik pengumpulan data merupakan langkah yang paling strategis dalam penelitian, karena tujuan utama dalam penelitian adalah mendapatkan data (Sugiyono, 2009: 62). Dalam melakukan penelitian, peneliti menggunakan teknik pengumpulan data melalui studi kepustakaan, pemberian tugas, wawancara dan angket.

Dalam penelitian kualitatif, yang menjadi instrumen atau alat penelitian adalah peneliti itu sendiri. Peneliti kualitatif sebagai human instrument, berfungsi sebagai sumber data, melakukan pengumpulan data, menilai kualitas data, analisis data, menafsirkan data, dan membuat kesimpulan atas temuannya (Sugiyono, 2009: 60).

Penganalisisan dan pendeskripsian data berdasarkan pada beberapa langkah. Pertama, peneliti mengambil data angket dan dianalisis. Data angket yang tidak sesuai dengan tujuan penelitian dipisahkan. Data-data yang diperoleh dari angket disebut data nonlinguistik. Kedua, peneliti menganalisis karangan siswa dan memisahkan data informasi interferensi morfologi dan interferensi sintaksis. Hasil analisis tersebut dideskripsikan dan dihitung jumlahnya untuk memperoleh gambaran mengenai interferensi morfologi dan interferensi sintaksis.

\section{HASIL DAN PEMBAHASAN}

Data nonlinguistik dalam penelitian ini bersumber dari angket yang diberikan kepada siswa dan wawancara terhadap guru bahasa. Informasi yang diperoleh dari angket dapat memperlihatkan apakah siswa seorang dwibahasawan atau bukan sedangkan wawancara dengan guru dapat memperlihatkan cara belajar dan berbahasa siswa di sekolah. 
Data yang diperoleh dari angket dimasukan ke dalam tabel berikut.

Tabel 1

Waktu Pemerolehan Bahasa

\begin{tabular}{|l|c|c|}
\hline \multicolumn{1}{|c|}{ Waktu Pemerolehan } & Bahasa Sunda & Bahasa Indonesia \\
\hline Sejak kecil & 62 & 35 \\
\hline Sejak Sekolah Dasar & 18 & 3 \\
\hline Lain-lain & 1 & 81 \\
\hline Jumlah & 81 & \\
\hline
\end{tabular}

Sumber: angket nomor 6 dan 8

Tabel 2

Tempat Pemerolehan Bahasa

\begin{tabular}{|l|c|c|}
\hline \multicolumn{1}{|c|}{ Tempat Pemerolehan } & Bahasa Sunda & Bahasa Indonesia \\
\hline Di rumah & 53 & 35 \\
\hline Di sekolah & 27 & 33 \\
\hline Lain-lain & 1 & 81 \\
\hline Jumlah & 81 & \\
\hline
\end{tabular}

Sumber: angket nomor 7 dan 9

sebesar $77 \%$ siswa memperoleh bahasa Sunda sejak kecil dan 22\% siswa mengaku memperoleh bahasa Sunda di Sekolah Dasar serta 1\% lain-lain. Hal ini tidak sejalan dengan data yang diperoleh bahwa rumah sebagai tempat pemerolehan bahasa kesatu bahasa Sunda. Sekitar 65\% siswa mengaku memperoleh bahasa Sunda di rumah dan 33\% mengaku memperoleh bahasa Sunda di Sekolah. Ada selisih sebesar 12\% siswa yang mengaku memperoleh bahasa Sunda sejak kecil, tetapi tempat pemerolehannnya di Sekolah Dasar.

Siswa yang berbahasa kesatu bahasa Sunda dan berbahasa kedua bahasa Indonesia tidak selalu menggunakan kedua bahasa tersebut secara bersamaan. Untuk lebih memahami seorang siswa dwibahasawan atau bukan, dapat dilihat dalam tabel berikut ini. 
Tabel 3

Intensitas Penggunaan Bahasa

\begin{tabular}{|l|c|c|c|c|}
\hline \multicolumn{1}{|c|}{ Tempat } & B. Sunda & B.Indonesia & Lain-lain & Jumlah \\
\hline di rumah & 71 & 8 & 2 & 81 \\
\hline di lingkungan masyarakat & 61 & 19 & 1 & 81 \\
\hline di sekolah dengan teman & 40 & 40 & 1 & 81 \\
\hline di sekolah dengan guru & 2 & 79 & & 81 \\
\hline
\end{tabular}

Sumber: angket nomor 2 s.d. 5

Dari data di atas dapat diketahui bahwa $88 \%$ siswa menggunakan bahasa Sunda di rumah dan $10 \%$ menggunakan bahasa Indonesia serta $2 \%$ sisanya menggunakan bahasa selain bahasa Sunda dan bahasa Indonesia.

Siswa berinteraksi menggunakan bahasa Sunda di lingkungan masyarakatnya sebesar $75 \%$ dan sebesar $23 \%$ menggunakan bahasa Indonesia serta $2 \%$ siswa yang menggunakan bahasa selain bahasa Sunda dan bahasa Indonesia.

Siswa yang berinteraksi dengan temannya menggunakan bahasa Sunda di sekolah sebesar 49\% dan 49\% lainnya menggunakan bahasa Indonesia. Kemungkinan penggunaan bahasa Sunda dilakukan secara informal di luar kelas atau didalam kelas dalam bentuk percakapan dengan teman, sedangkan penggunaan bahasa Indonesia dilakukan di dalam kelas pada saat pembelajaran secara formal dan di luar kelas dengan siswa yang memang tidak memahami bahasa Sunda.

Sebaliknya, hanya $2 \%$ saja yang menggunakan bahasa Sunda untuk berinteraksi dengan guru. Sisanya sebesar 98\% menggunakan bahasa Indonesia. Sesuai dengan fungsi bahasa Indonesia dalam ragam resmi bahwa bahasa Indonesia digunakan sebagai bahasa pengantar di sekolah.

Dari informasi data nonlinguistik tersebut, peneliti memutuskan untuk membatasi objek penelitian hanya pada siswa yang memiliki bahasa ibu bahasa Sunda saja. Sesuai dengan data pada tabel 1 yaitu sebanyak 62 siswa.

Interferensi morfologi menurut Aslinda dan Syafyahya (2014: 75) interferensi dalam bidang morfologi dapat terjadi antara lain pada penggunaan unsur-unsur pembentukan kata, pola proses morfologi, dan proses penanggalan afiks.

Salah satu contoh interferensi morfologi yaitu interferensi yang terjadi pada pola proses morfologi pada kata mengcat yang seharusnya dalam bahasa Indonesia adalah mengecat. Kata mengcat terinterferensi dari bahasa Sunda ngecet.

Selain kata mengcat ada juga kata mengecet. Kata ini menggunakan awalan meng- yang mengalami penasalan menge- karena bertemu dengan kata yang terdiri dari 3 huruf. Kata mengecet juga terinterferensi dari kata ngecet.

Demikian juga halnya dengan dicet yang dalam bahasa Indonesia adalah dicat bentuk pasif dari mengecat. Pemberian awalan di- melekat pada kata cet kata dari bahasa Sunda yang berarti cat. 
Interferensi prefiks terjadi juga pada kata pengapus. Dalam bahasa Sunda ditemukan kata pangapus yaitu alat untuk menghapus, sedangkan dalam bahasa Indonesia kata yang searti adalah penghapus. Dalam hal ini, terjadi pencampuran awalan pang- dengan awalan peng- yang memiliki arti sama yaitu awalan untuk menyatakan alat.

Dari analisis intereferensi morfologi diperoleh jumlah kata yang terinterferensi sebanyak 297 kata dari total jumlah kata semua karangan 11.382 kata. Sesuai dengan rumus yang telah dijelaskan pada bab tiga, yaitu $\frac{n}{\mathrm{~N}} \times 100 \%=\cdots \%$ maka $\frac{297}{11382} \times 100 \%=$ $2,6 \%]$ jumlah kata yang terinterferensi adalah 2,6\%. Artinya, secara keseluruhan karangan 62 siswa SMPN 1 Nanggung, Kabupaten Bogor tahun pelajaran 2018/2019 kurang terdapat interferensi morfologi karena berada pada rentang 0\% - 30\%.

Jika dilihat dari karangan perorangan, terdapat 12 karangan yang tidak memiliki interferensi morfologi yaitu nomor 8,10, 11, 15, 18, 44, 50, 56, 62, 71, 74, dan 78. Karangan yang memiliki interferensi morfologi paling tinggi adalah karangan nomor 36 sebesar $37 \%$.

Menurut Aslinda dan Syafyahya (2014: 82) interferensi bidang sintaksis antara lain meliputi penggunaan kata tugas bahasa pertama pada bahasa kedua atau sebaliknya.

Interferensi sintaksis terjadi apabila struktur bahasa lain dalam hal ini bahasa Sunda digunakan dalam pembentukan kalimat bahasa yang digunakan atau bahasa Indonesia. Penyerapan unsur kalimatnya dapat berupa kata, frasa, dan klausa.

Struktur kalimat adalah bagian-bagian kalimat yang dapat membentuk suatu kalimat yang terdiri dari beberapa kata. Penyerapan struktur kalimat terjadi pada kalimat berikut,

a) Semoga ke depannya sekolah ini sangat rapi dan bersih.

b) Semoga SMPN 1 Nanggung kedepannya lebih maju.

Pada kalimat (a) dan (b) kata 'ke depannya' menyatakan waktu. Jika melihat maknanya kalimat tersebut dapat disubtitusi menjadi "Semoga nanti sekolah ini rapi dan bersih sekali." dan "Semoga SMPN 1 Nanggung kelak semakin maju" atau "Semoga SMPN 1 Nanggung akan semakin maju di masa yang akan datang." Sebaliknya, dalam bahasa Sunda kedua struktur kalimat tersebut dapat diterima seperti di bawah ini.

a) Mugia kapayuna sakola ieu rapih jeung bersih pisan.

b) Mugia SMPN 1 Nanggung kapayunna langkung maju.

Dari analisis interferensi sintaksis diperoleh jumlah kalimat yang terinterferensi sebesar 64 kalimat dari total jumlah kalimat semua karangan 1.129 kalimat. Sesuai dengan rumus yang telah dijelaskan pada bab tiga, yaitu

$\frac{n}{\mathrm{~N}} \times 100 \%=\cdots \% \quad$ maka $\quad \frac{64}{1129} \times 100 \%=5,7 \% \square \quad$ jumlah kalimat yang terinterferensi adalah 5,7\%. Artinya, secara keseluruhan 62 karangan siswa SMPN 1 Nanggung, Kabupaten Bogor tahun pelajaran 2018/2019 kurang terdapat interferensi sintaksis karena berada pada rentang $0 \%-30 \%$.

Dilihat dari perorangan, karangan nomor 59 melakukan paling banyak interferensi sintaksis yaitu sebesar 11 kalimat dari 22 kalimat atau sama dengan 50\%. Dilihat dari kriterianya, jumlah tersebut menunjukkan bahwa karangan nomor 59 cukup banyak melakukan interferensi karena berada pada rentang $\quad 31 \%-60 \%$.

Hasil analisis kedua aspek interferensi yaitu morfologi dan sintaksis menggambarkan bahwa karangan yang mengandung interferensi morfologi sebanyak 50 karangan atau 80,6\% dan karangan yang mengandung interferensi sintaksis sebanyak 30 karangan atau 48,4\%. 
Secara keseluruhan hampir semua karangan mengandung interferensi. Hanya ada 5 karangan yang sama sekali tidak mengandung interferensi yaitu karangan nomor 44, 50, 56, 62, dan 78. Berarti sekitar 91,9\% karangan mengandung interferensi baik interferensi morfologi maupun sintaksis.

\section{Simpulan}

Interferensi morfologi dan sintaksis bahasa Sunda terhadap bahasa Indonesia terjadi dalam karangan siswa kelas VII SMPN 1 Nanggung, Kabupaten Bogor tahun pelajaran 2018/2019. Dari 62 karangan yang diteliti, sebanyak 57 karangan mengandung interferensi, sedangkan sisanya sama sekali tidak mengandung interferensi.

Aspek kebahasaan yang paling banyak mengalami interferensi adalah aspek morfologi terutama interferensi bentuk kata. Karangan yang mengandung interferensi morfologi sebanyak 50 karangan atau 80,6\% dan karangan yang mengandung interferensi sintaksis sebanyak 30 karangan atau 48,4\%. Secara keseluruhan hampir semua karangan mengandung interferensi meskipun intensitasnya rendah. Hanya ada 5 karangan yang sama sekali tidak mengandung interferensi yaitu karangan nomor 44, 50, 56, 62, dan 78. Berarti sekitar 91,9\% karangan mengandung interferensi baik interferensi morfologi maupun sintaksis.

Secara keseluruhan karangan siswa kelas VII SMPN 1 Nanggung, Kabupaten Bogor tahun pelajaran 2018/2019 berkategori kurang dalam melakukan interferensi. Dalam interefensi morfologi, penghitungan bentuk kata dan kata berimbuhan yang terinterferensi sebanyak 2,6\%, sedangkan interferensi sintaksis dihitung dari frasa, klausa, kalimat yang terinterferensi dengan keseluruhan kalimat hanya diperoleh angka 5,7\%.

Faktor-faktor penyebab terjadinya interferensi berdasarkan data-data nonlinguistik adalah

a) Pemakaian bahasa Sunda yang dominan dalam kehidupan sehari-hari siswa baik itu di lingkungan rumah maupun sekolah.

b) Kemiripan atau ketiadaan padanan dalam bahasa Sunda dengan bahasa Indonesia atau sebaliknya.

Dari simpulan di atas, kita dapat memahami bahwa anak-anak akan mengalami interferensi dalam bahasa lisan atau tulisan selama mereka menggunakan dua bahasa atau lebih. Sekali pun mereka tidak menggunakan bahasa daerah, melainkan bahasa asing. Selalu ada kemungkinan untuk melakukan interferensi. Namun, semakin bertambah usia seseorang interferensi semakin kecil terjadi. Hal ini dikarenakan daya pikir atau cara bernalar sudah lebih baik sehingga seseorang akan berbahasa dengan lebih berhati-hati dan menyadari jika melakukan kesalahan atau kekeliruan dalam berbahasa. 


\section{DAFTAR PUSTAKA}

Alwasilah, C.1989. Sosiologi Bahasa. Bandung: Angkasa.

Andriani, A.1999. "Interferensi Bahasa Sunda terhadap Bahasa Indonesia dalam Karangan Siswa SD Kelas V di Sukabumi”. Skripsi. Jurusan Pendidikan Bahasa dan Sastra Indonesia, FPBS, IKIP Bandung.

Arikunto, S. 2010. Prosedur Penelitian Suatu Pendekatan Praktik. Jakarta: Pustaka Jaya.

Aslinda dan Syafyahya, L. 2014. Pengantar Sosiolinguistik. Bandung. PT Refika Aditama.

Budiarti, A. 2013. Interferensi Bahasa Indonesia ke dalam Bahasa Inggris pada Abstrak Jurnal Ilmiah. Jurnal Bahasa dan Seni. 41 (1) hlm.10--17

Chaer, A dan Agustina, L. 2010. Sosiolinguistik Perkenalan Awal. Edisi Revisi. Jakarta: Rineka Cipta.

Chaer, A. 2003. Psikolinguistik Kajian Teoritik.. Jakarta: Rineka Cipta.

Coulmas, F. 2000. Sociolinguistics the Study of Speaker Choice. New York: Cambridge University. Kuantitatif dan Mixed. Cetakan ke-2. Terjemahan Achmad Fawaid. Yogyakarta: Pustaka Pelajar.

Departemen Pendidikan Nasional. 2008. Kamus Besar Bahasa Indonesia. Jakarta: Gramedia Pustaka Utama.

Fauziati, E. 2016. "Interferensi Gramatikal Bahasa Indonesia dalam Bahasa Inggris: Kasus pada Buku LKS Bahasa Inggris untuk SLTP di Surakarta”. Jurnal Penelitian Humaniora, 17(2) hlm. 96-109.

Hartmann,R.R.K., \& Stork, F.C. 1972. Dictionary of Language and Linguistics. London: Applied Science.

Keraf, G. 1994. Komposisi. Ende-Flores: Nusa Indah.

Kridalaksana, H. 2008. Pembentukan Kata dalam Bahasa Indonesia. Jakarta: Gramedia.

Lapasau, M. dan E. Z. Arifin. 2016. Sosiolinguistik. Jakarta: Pustaka Mandiri.

Lembaga Basa dan Sastra Sunda. 1992. Kamus Umum Basa Sunda. Bandung: Penerbit Tarate. 